Max-Planck-Institut für demografische Forschung

Max Planck Institute for Demographic Research

Konrad-Zuse-Strasse 1 - D-18057 Rostock - GERMANY

Tel +49 (0) 3812081 - 0; Fax +49 (0) 3812081 - 202;

http://www.demogr.mpg.de

MPIDR WORKING PAPER WP 2003-020

JULY 2003

\title{
Association of Late Childbearing with Healthy Longevity among the Oldest-Old in China
}

Zeng Yi

James W. Vaupel (jwv@demogr.mpg.de)

(C) Copyright is held by the authors.

Working papers of the Max Planck Institute for Demographic Research receive only limited review.

Views or opinions expressed in working papers are attributable to the authors and do not necessarily reflect those of the Institute. 


\section{ASSOCIATION OF LATE CHILDBEARING WITH HEALTHY LONGEVITY AMONG THE OLDEST-OLD IN CHINA 1}

Zeng Yi and James W. Vaupel 2

Short Title: Late Childbearing and Healthy Longevity, China

\footnotetext{
1 This article is based on data derived from the Chinese Healthy Longevity Survey, which was supported by NIA/NIH grant P01 AG 08761 awarded to Duke University and Chinese matching input towards personnel costs and some local expenses. The Max Planck Institute for Demographic Research provided support for international training. We thank Gu Danan for his excellent research assistance and comments.

${ }^{2}$ Zeng Yi is Research Professor at the Center for Demographic Studies and the Department of Sociology of Duke University, Professor of Peking University, and Distinguished Research Scholar at the Max Planck Institute for Demographic Research. James W. Vaupel is Founding Director of the Max Planck Institute for Demographic Research and Senior Research Scientist at Duke University.
} 


\title{
ASSOCIATION OF LATE CHILDBEARING WITH HEALTHY LONGEVITY AMONG THE OLDEST-OLD IN CHINA
}

\begin{abstract}
Statistical analysis of a large and unique longitudinal data set demonstrates that late childbearing after age 35 or 40 is significantly associated with survival and healthy survival among very old Chinese women and men. The association is stronger in oldest-old women than men. The estimates are adjusted for a variety of confounding factors of demographic characteristics, family support, social connections, health practices, and health conditions. Further analysis based on an extension of the Fixed Attribute Dynamics method shows that late childbearing is positively associated with long-term survival and healthy survival from ages 80-85 to 90-95 and 100-105. This association exists among oldest-old women and men, but, again, the effects are substantially stronger in women than men. We discuss four possible factors which may explain why late childbearing affects healthy longevity at advanced ages: (1) social factors; (2) biological changes caused by late pregnancy and delivery; (3) genetic and other biological characteristics; and (4) selection.
\end{abstract}

\section{INTRODUCTION}

This article focuses on the association between late childbearing and healthy longevity. Doblhammer (2000) and Perls, Alpert and Fretts (1997) investigate the association between late childbearing and longevity for women. Smith, Mineau and Bean (2003) explore the association for men as well as women, as we do here. Unlike previous studies, we analyze healthy longevity and longevity per se. Furthermore, we use an unprecedentedly large follow-up sample of nearly 9,000 
elderly people, aged 80 to 105 , including 2,400 centenarians. This sample is from China, a developing country where the chance of surviving from birth to advanced old age was very low compared to the cohorts of Americans and Europeans studied by Doblhammer (2000), Perls et al. (1997), and Smith et al. (2003).

Our research is part of a broader literature on how events early in life - in uterus, in childhood, in adult ages before 50 or so, and genetically predetermined characteristics - affect health and survival at older ages. Nearly all this literature focuses on ages younger than 80 . Notable exceptions are a study by Preston, Hill, and Drevenstedt (1998) of African American cohorts born at the beginning of the $20^{\text {th }}$ century, a study by Snowdon (2001) of elderly nuns, and a study by Doblhammer and Vaupel (2001) of how month of birth influences longevity. Our study is also part of the literature on the determinants of healthy longevity, especially about the determinants of exceptional longevity or about the determinants of health among the oldest-old aged 80 or above (e.g. Perls et al., 2000; Christensen and Vaupel, 1996; Hitt, Young-Xu, and Perls, 1999; Puca et al. 2001; Kerber et al. 2001; Barzilai, 1998).

We apply logistic and survival-analysis models to health data and follow-up mortality data collected from 1998 to 2000 for nearly 9,000 Chinese elderly aged 80 and above. In our analyses, we adjust for a variety of confounding factors. We then use an extended Fixed-Attributes Dynamics (FAD) method and the 1998 baseline survey data to investigate the association of late childbearing with healthy longevity from age 80-85 to 90-95 and 100-105.

\section{DATA RESOURCE AND MEASUREMENTS}

Data used in this article are from the Chinese Longitudinal Survey on Healthy Longevity, which is the largest longitudinal study of very old people in a developing country; it is also the largest 
longitudinal study of centenarians, nonagenarians, and octogenarians conducted anywhere. The baseline survey and the first follow-up survey were conducted in 1998 and 2000. They were carried out in 631 and 777 counties/cities in 1998 and 2000, respectively, randomly selected about half of the counties and cities in 22 Chinese provinces. The increase in numbers of survey units was partly due to some townships which belonged to a county became a city in the later wave, and partly due to some selected counties/cities that had no centenarians in 1998 but had centenarians in 2000 (see discussion below on centenarians). The 22 surveyed provinces are Liaoning, Jilin, Heilongjiang, Hebei, Beijing, Tianjing, Shanxi, Shaanxi, Shanghai, Jiangsu, Zhejiang, Anhui, Fujian, Jiangxi, Shangdong, Henan, Hubei, Hunan, Guangdong, Guangxi, Sichuan, Chongqing (there are 31 provinces in total in China). These provinces have a population of 985 million, constituting 85 percent of the total population of China. An interview and a basic health examination were conducted at the interviewee's home. The data collected include family structure; living arrangement; number, age, and proximity of children; Activities of Daily Living (ADL); self-rated health; self-evaluation of life satisfaction; cognitive function; medical care; social and religious activities; diet; smoking and alcohol consumption; psychological characteristics; economic resources; caregivers and family support; and other information.

The survey team tried to interview all centenarians who voluntarily agreed to participate in the study. For each centenarian, the survey team tried to interview one near-by octogenarian (aged 80-89) and one near-by nonagenarian (aged 90-99) of a pre-designated single year of age and sex. The term "near-by" is loosely defined to include the same village or the same street or, if applicable, the same town, county or city. The predefined age and sex that are used to ensure that approximately equal numbers of male and female nonagenarians and octogenarians were randomly determined, based on the code numbers of the centenarians. The aim was to have more or less randomly selected comparable 
numbers of male and female octogenarians and nonagenarians at each age from 80 to 99 (see endnote 4 in Zeng, Vaupel et al. 2002 for details). The total valid sample size of the baseline data set used in this article is 8,805 elders aged 80 to 105 , including 458 male and 1,806 female centenarians, 1,298 male and 1,714 female nonagenarians, and 1,787 male and 1,741 female octogenarians.

Of the participants in the 1998 baseline survey, 4,691 (53.3\%) were alive and re-interviewed in the second wave in $2000 ; 3,264(37.1 \%)$ were dead and their date and cause of death, and health status before dying were collected through interviewing one of their close family members; and 850 (9.6\%) could not be followed up in the second wave. Survival time for decedents or censoring time for survivors was calculated in days between the date of the baseline interview and the date of death or second interview. The 844 individuals who could not be followed up (mainly due to change in residence) were excluded from this study because we do not know whether they survived or died.

Coale and Li (1991) concluded that the reported age of very old persons in these provinces of China where Han Chinese constitute the majority were as reliable as reports in developed countries. But in other regions (such as Xingjiang), where the majority or a significant proportion of the population belongs to ethnic groups other than the Han, age reporting may be inaccurate. This is the main reason why we restrict our survey to the 22 provinces where Han Chinese are the overwhelming majority. The other nine provinces (Xinjiang, Qinghai, Ningxia, Inner Mongolia, Tibet, Gansu, Yunnan, Guizhou, and Hainan), all of which have a high proportion of inhabitants belonging to ethnic minorities, are not included in this study. While we are sure that the quality of age reporting is very poor in Xinjiang, it is not certain that the quality is poor or acceptable for all other ethnic minority groups in the other eight provinces that were not included in the survey. We did not include them because we are not sure about the quality of the age reporting of the ethnic 
minority groups in these eight provinces, and we had no detailed age-ethnic-specific data to evaluate them, and due to fund constraints.

A study focusing on the age validation of Chinese Han centenarians through comparison of demographic indices with Sweden, Japan, France, and Italy is consistent with Coale and Li's findings (Wang, Zeng, Vaupel, and Jeune1998). A fairly close similarity of age distribution of the centenarians interviewed in our 1998 survey and that of Swedish centenarians was found (see Figure 1 in Zeng, Vaupel et al. 2001). These findings lead us to believe that age reporting in the Chinese Healthy Longevity Survey is generally acceptable up to age 105. A careful evaluation (based on reliability coefficients, factor analysis, the rates of logically inconsistent answers, etc.) showed that the data quality of the Chinese survey on healthy longevity is generally good (Zeng, Vaupel et al. 2001; Zeng, Vaupel et al. 2002). The reliability coefficients of the 10 categories of variables are reasonable (e.g., see Table 3 in Zeng and Vaupel et al., 2001). For example, the ADL reliability coefficient is 0.88 and 0.87 in the 1998 and 2000 surveys, respectively, as compared to 0.87 in the Duke Older Americans Resources and Services Program survey (Fillenbaum, 1988) and 0.89 in the Canadian 1991-1992 elderly survey (Penning and Laurel, 1994). The factor analysis demonstrates that the interviewees' answers to questions within the same category but concerning different aspects are generally consistent. The rates of logically inconsistent answers and "missing" data are reasonably low (see Appendix B in Zeng and Vaupel et al., 2001).

The frequency distributions of the covariates used in this article, based on the 1998 baseline survey, are listed in Table 1. These variables are chosen because of their potential association with survival or health status. Following similar studies (e.g., Clark, Stump, \& Hui 1998; Koenig et al. 1999; Landerman \& Fillenbaum 1997; Palmore \& Burhcett 1997; Smith \& Kington 1997; Strawbridge et al. 1997), all variables were dichotomized, except age, number of births after age 35 or 40 , age at $1^{\text {st }}$ 
marriage, and number of surviving children.

--Table 1 is about here-

Late childbearing was measured by the number of births after age 35 and age 40 .

Demographic variables include age (80-89, 90-99, 100-105), gender (male, female), ethnicity (Han, minorities), education ( 0 years of schooling, $\geq 1$ year schooling), age at $1^{\text {st }}$ marriage, and residence (rural, urban).

Physical and mental health variables include ADL, cognitive function measured by MMSE, selfrated health, and depression symptoms.

Family support includes marital status, number of surviving children at the time of the 1998 survey, proximity with children, and religious attendance.

The social connection/support index was based on questions about playing cards or mah-jong regularly, watching TV or listening to the radio regularly, retirement wages, adequate medical service, and caregivers.

Health Practice includes cigarette smoking, alcohol consumption, diet, and exercise.

More detailed descriptions of the covariates listed above and included in our models are presented in the Appendix. Since the percentages of missing values (excluding "not able to answer") of all variables at baseline used in our models are less than $2 \%$ except age at $1^{\text {st }}$ marriage (5\%), we imputed missing values with the mean of the variable (Landerman, Land, and Pieper, 1997) except age at $1^{\text {st }}$ marriage with multiple imputation (Allison, 2002).

\section{METHODS}

\section{Statistical modeling}

We performed three kinds of statistical analysis. First, we used logistic regression to analyze how 
late childbearing is associated with health status. In such models, the dependent variables are ADL scores, MMSE (Mini Mental Status Exam) scores, self-rated health, and depression symptoms. The independent variables are late childbearing after age 35 or 40, plus other covariates measuring demographic characteristics, family support, social connections, and health practice (to be described later).

Second, we used a Cox proportional hazards regression model (Cox, 1972) to examine the association between late childbearing and survival, controlling for confounding factors. The proportionality hypothesis was tested graphically and with the normal score test (Grambsch and Therneau 1994), and confirmed. Survival time from the interview in 1998 to death or re-interview in 2000 was measured in days.

Third, we used ordinal logistic regression (Harrell, 2001: 331; Meurer et al. 2001) to investigate the association of late childbearing with healthy survival, adjusting for confounding factors (the proportional odds assumption required for ordinal logistic regression was tested and met for both males and females). The dependent variable was defined as follows. The individuals who survived with good health in the second wave (2000) were coded as 1; those who survived with poor health were coded as 2; those who died between the two waves (1998-2000) were coded as 3. "Good health" is defined as no impairment in ADL, normal cognitive function, self-reported good health and no depression symptoms (measurement issues will be discussed later). Persons who are not in "good health" are considered to be in "poor health".

We employed a sequential modeling strategy (e.g., Koenig et al. 1999; Strawbridge et al. 1997) in our Cox survival analysis and ordinal logistic regression analysis. In our sequential models, Model I adjusts for demographic variables of gender, age, rural/urban residence, education, and ethnicity. Model II further adjusts for family support and social connection variables pertaining to the number of 
surviving children, marital status, living arrangement, proximity with children, religious attendance, social contacts, retirement wage, adequate medical care, and caregiver, in addition to the demographic variables. Model III adds health practice variables pertaining to smoking, alcohol drinking, diet, and exercise. Model IV further controls for health status as measured by ADL limitations, MMSE score, self-reported health, and depression symptoms. All of the values of the covariates of Models I, II, III, and IV in the analyses presented in Tables 3 and 4 are obtained from the 1998 baseline survey. The sequential models allow us to examine how the estimated association of late childbearing with survival and healthy survival is affected when confounding factors are added to the model step by step. The likelihood ratio tests show that the goodness of fit of our models is improved significantly as additional factors are added (see Table 3).

\section{Fixed-Attribute Dynamics (FAD) Method}

The models and data described above can be used to explore the effects of late childbearing on survival and healthy survival from age $\mathrm{x}$ to $\mathrm{x}+2$. Because the longitudinal data are only available for two years, these analyses cannot be used to investigate the association of late childbearing with healthy survival over long intervals. Hence, we apply a FAD (Fixed Attribute Dynamics) method to be extended in this article to study the association of late childbearing with healthy longevity from ages $80-85$ to $90-95$ and $100-105$.

The idea of the FAD method, also known as the Survival Attribute Assay, was initially proposed by James Vaupel (Vaupel 1992, formulas 9.12 and 9.17) and developed by him and Anatoli Yashin in a series of articles (Yashin et al. 1998; 1999; 2000; Gerdes et al. 2000). The method is based on the fundamental demographic insight that the prevalence of a fixed attribute in a population can change with age even though no individual can change his or her variant, and that much, thereby, 
can be learned about the impact of the attribute on survival. Fixed attributes that affect survival at older ages include genetic factors and various non-genetic factors that are fixed in earlier life. Such factors could be fixed at birth (e.g., genetic make-up, birth weight, and birth order). Any factor that is fixed by old age (e.g., diseases suffered earlier in life, education, occupation, and pattern of childbearing), however, could also be used in a study of survival at older ages.

The basic FAD method for use in a study of longevity can be formulated as follows. Let $N(x)$ denote the number of persons aged $\mathrm{x} ; p_{1}(x)$, the proportion of individuals who are $\mathrm{x}$ years old and have the fixed attribute; $s_{1}(x+n)$, the conditional survival probability from age $\mathrm{x}$ to $\mathrm{x}+\mathrm{n}$ for those who have the fixed attribute; $s_{\mathrm{o}}(x+n)$, the conditional survival probability from age $\mathrm{x}$ to $\mathrm{x}+\mathrm{n}$ for those who do not have the fixed attribute; and $S(x+n)$, the conditional survival probability from age $\mathrm{x}$ to $\mathrm{x}+\mathrm{n}$ for all members of the cohort.

On the one hand, because $N(x) p_{1}(x) s_{1}(x+n)=N(x) S(x+n) p_{1}(x+n)$, it follows that

$$
S_{1}(x+n)=S(x+n)\left(\frac{p_{1}(x+n)}{p_{1}(x)}\right) .
$$

On the other hand, it similarly follows that

$$
s_{0}(x+n)=S(x+n)\left(\frac{1-p_{1}(x+n)}{1-p_{1}(x)}\right)
$$

Dividing (1) by (2) gives the Ratio of Survivorship $(R S)$ of those with the fixed attribute to those without the attribute:

$$
R S=\frac{s_{1}(x+n)}{s_{0}(x+n)}=\frac{\left(1-p_{1}(x)\right) p_{1}(x+n)}{p_{1}(x)\left(1-p_{1}(x+n)\right)} .
$$

If the Ratio of Survivorship $R S$ is greater than one, the attribute is positively associated with longevity. Statistical tests can be performed based on the method developed by Mantel and Haenszel 
(1959) to test whether there is a statistically significant difference of survivorship between those with the fixed attribute and those without the fixed attribute (i.e., to test the null hypothesis that the ratio of survivorship equals one).

The research by Vaupel, Yashin, and colleagues using the FAD method is based on the use of formulas (1) and (2) to derive estimates of the relative risk of mortality for people with some attribute versus people without the attribute (Yashin et al. 1998; 1999; 2000; Gerdes et al. 2000). In this article, however, we will emphasize the use of formula (3). Formula (3) does not require estimates of cohort survivorship ( $\mathrm{S}(\mathrm{x})$ ), which are not available for this study and may not be available for many other studies, especially for developing countries.

We extend the FAD method expressed in formula (3) to study the association between a fixed attribute and the combined status of survival and good health. Good health is defined by some measure, such as "ADL independence", the ability to independently perform basic activities of daily living. Let $l_{1}(x+n)$ denote the probability that individuals who are $\mathrm{x}$ years old and who have some fixed attribute will survive to age $x+n$ and be in good health at age $x+n$. Note that these individuals do not have to be in good health at age $\mathrm{x}$. Similarly, define $l_{0}(x+n)$ as the probability that individuals who are $\mathrm{x}$ years old and who do not have the fixed attribute will survive to age $\mathrm{x}+\mathrm{n}$ and be in good health at age $\mathrm{x}+\mathrm{n}$. Let $h(x+n)$ be the proportion of persons who are in good health at age $\mathrm{x}+\mathrm{n}$. Finally, let $\pi(x+n)$ be the proportion of persons having the fixed attribute among those who are healthy at age $x+n$.

On the one hand, because $N(x) p_{1}(x) l_{1}(x+n)=N(x) S(x+n) h(x+n) \pi(x+n)$, it follows that

$$
l_{1}(x+n)=\frac{S(x+n) h(x+n) \pi(x+n)}{p_{1}(x)}
$$

where $S(x)$ and $p_{l}(x)$ are defined as before. On the other hand, it is also the case that 


$$
l_{0}(x+n)=\frac{S(x+n) h(x+n)(1-\pi(x+n))}{\left(1-p_{1}(x)\right)}
$$

The ratio of the healthy survival probability for those with the fixed attribute to the healthy survival probability for cohort members without the fixed attribute, which we call the Ratio of Healthy Survivorship (RHS), is estimated by dividing formula (4) by formula (5):

$$
R H S=\frac{l_{1}(x+n)}{l_{0}(x+n)}=\frac{\left(1-p_{1}(x)\right) \pi(x+n)}{p_{1}(x)(1-\pi(x+n))} .
$$

If the Ratio of Healthy Survivorship RHS is greater than one, the fixed attribute is positively associated with healthy longevity.

Formula (6) is an extension of formula (3). Note that formula (3) can be expressed in terms of the number of people with and without some attribute at two ages:

$$
R S=\frac{N_{0}(x) N_{1}(x+n)}{N_{1}(x) N_{0}(x+n)} .
$$

This is a formula used by Hill (1999). So the method expressed in formula (6) can be considered to be an extension both of the FAD method and of Hill's approach.

One of the main strengths of the FAD method is that it can be used to analyze the association between fixed attributes and longevity or healthy longevity based on two or more independent crosssectional samples, rather than on a longitudinal survey. The ratios of survivorship and healthy survivorship using the FAD method can also be estimated on the basis of one cross-sectional data set. This can be done if it is reasonable to assume that the initial distribution of the fixed attribute and its effects on survival do not differ substantially between older and younger cohorts. In this case, the older and younger cohorts are connected in one hypothetical cohort. As will be discussed later, we assume that the initial distributions of late childbearing - and the effect of this fixed attribute on healthy survival—did not differ significantly among the cohorts aged 80-105 in 1998. 
The FAD method assumes that the number of migrants is small or, alternatively, migrants do not differ significantly from non-migrants with respect to the fixed attribute and survival. The magnitude of international and internal migration before the 1980s in China was small due to slow economic development and policies restricting residential movement. Mobility greatly increased after 1980, but not among the oldest-old.

A major limitation of the standard approaches to survival analysis is the need for prospective tracking of study participants to ascertain the occurrence of exit events. If the transition of interest requires many years to occur, the required follow-up period often becomes prohibitively expensive and time-consuming (Hill 1999: 497-498). The main strength of the FAD method is that it circumvents this major limitation. In the present study, one of the objectives is to investigate the association of late childbearing with healthy longevity from age 80-85 to 90-95 and 100-105. To do so, and using the standard approach of survival analysis, we would need 10-20 years of follow-up data, which is not available. Furthermore, almost all of the oldest-old aged 80-105 would die within the 10-20 year follow-up period even if such a study were practicable. This is the main reason why we use the FAD method based on the cross-sectional baseline survey data, in addition to the survival analysis using the baseline and the two-year follow-up data.

The strength of the FAD method, however, is bought at a price. The FAD method has a major limitation. In addition to its crucial assumptions, as discussed earlier, the FAD method, as currently developed, permits a univariate analysis to ascertain the "de facto" association between the fixed attribute and survival, while controlling for age and sex. An analysis based on the FAD method does not ascertain whether the association of the fixed attribute with healthy survival is due to the attribute itself or is caused or mediated by other factors. This is why we also use logistic analysis and hazards models to investigate the associations of late childbearing with health status at the 
baseline and with survival and healthy survival during the 1998-2000 follow-up period.

\section{FINDINGS}

\section{Results based on the Statistical Models and the 1998-2000 Survey Data}

The association of late childbearing with health status in the1998 baseline survey

Table 2 shows the estimates of the odds ratios (OR) of being ADL disabled, MMSE abnormal, having self-reported poor health, and having depression symptoms (we are satisfied with the goodness of fit of the logistic regression models presented in Table 2, based on the Chi-square tests suggested by Hosmer-Lemeshow, 1989). These estimates enable comparison of health status in the 1998 baseline survey between the oldest-old who had 1, 2, or $3+$ births after age 35 or 40 with those who did not have late births. The estimates of the odds ratios are adjusted for 16 confounding factors of demographic characteristics, family support, social connections, and health practice, as listed in Table 1. 43 out of 48 estimates of the odds ratios of being in poor health presented in Table 2 are less than one; 5 odds ratios are greater than one but not statistically significant; among the odds ratios that are less than one, 10 are statistically significant at different levels. For instance, the odds ratio of being ADL disabled for very old women who gave $3+$ births after age 35 or 40 is 0.77 or 0.48 ; the estimate is statistically significant at a level of $\mathrm{p}<0.05$ or $\mathrm{p}<0.001$. This means that, controlling for the other 16 confounding factors of demographic characteristics, family support, social connections, and health practice, the likelihood of being ADL disabled for the women who gave $3+$ births after age 35 or age 40 is 23 or 52 percent lower than that of those who did not have such late births. While controlling for the confounding factors, the oldest-old women and men who had 1, 2, or 3+ births after age 35 or 40 tend somewhat less likely to be ADL disabled, MMSE abnormal, have selfreported poor health and having depression symptoms. The general pattern is clear: late childbearing 
may be associated with better health at advanced ages; and in most cases, the larger the number of births after age 35 or 40 , the stronger the association. Most of the estimates are not statistically significant, however. Thus, we must be cautious in making conclusions about the degree of the association of late childbearing with health status among the oldest-old.

---Table 2 is about here--

The association of late childbearing with survival

The second and third columns in Table 3 present the Relative Mortality Risk (RMR) between 1998 and 2000 for the oldest-old who had 1, 2, or 3+ births after age 35 or 40 versus those who did not have late births. In all Models (I, II, III, and IV), the mortality risk of very old females who had 1 birth after age 35 or age 40 did not differ significantly from those who did not have late births. Adjusted for age, residence, education, age at $1^{\text {st }}$ marriage, and ethnicity (Model I), the mortality risk of women who had $3+$ births after age 35 or had 2 or $3+$ births after age 40 was reduced by 28,21 , or 43 percent, respectively, as compared with those who did not have late births. These estimates are statistically significant. After the covariates of family support, social connection, and health practice were added to the model (II and III), the impact of late childbearing on reducing the relative mortality risk of women remains almost the same as that estimated in Model I, which adjusted for demographic variables only.

---Table 3 is about here---

Model IV, which further adjusts health status, shows that the mortality risk of oldest-old women who had $3+$ births after age 35 or had 2 or $3+$ births after age 40 remains significantly lower than that of those who had no late births. More specifically, controlling for 20 covariates including ADL, MMSE, self-reported health, depression symptoms, health practice, family support, social connections, and demographic characteristics, the mortality risk of very old females who had 2 or $3+$ 
births after age 40 is 19 and 38 percent lower than that of those who had no late births. The mortality risk of women who had $3+$ births after age 35 is 23 percent lower than that of those who had no late births.

It is remarkable that we found that late childbearing is associated with lower mortality risk among very old males, as well. Controlling for the demographic characteristics of age, residence, education, age at $1^{\text {st }}$ marriage, and ethnicity, having 2 or $3+$ births after age 40 reduces the 2 -yearperiod mortality risk of the oldest-old men by 20 or 33 percent. After the covariates of family support (including the number of surviving children), social connections, and health practice are added to the model, having 2 or $3+$ births after age 40 still reduces the 2 -year-period mortality risk of the oldest-old men by 20-26 percent. Even after ADL, MMSE, self-reported health, and depression symptoms are added to Model IV, in addition to demographic characteristics, family support, social connections, and health practice as controlling variables, very old males who had 2 or $3+$ births after age 40 still had about a 16-22 percent lower risk of death. These estimates are all statistically significant (see Table 3).

The estimates show that the addition of the covariates of family support (including the number of surviving children) and social connections as controlling variables to Model II slightly weakens the association between late childbearing and survival among the oldest-old men, as compared to Model I. Additions of the covariates of health practice and health conditions to the models for males further weaken the association. The survival analysis also demonstrates that in all cases of Models I, II, III, and IV, the larger the number of births after age 35 or 40 , the stronger the association between late childbearing and survival among both male and female oldest-old (see Table 3).

\section{The association of late childbearing with healthy survival}

The last two columns of Table 3 present the ordinal logistic regression estimates of the association of late childbearing with healthy survival, sequentially adjusted for the 20 covariates of demographic 
characteristics, family support, social connections, health practice, and health conditions observed in the 1998 baseline survey. As described earlier, healthy survival is defined as survival plus good health in the second wave of the survey in 2000. "Good health" is measured by "no impairment" in all of the four main aspects of health, namely, being active in daily living, normal cognitive function, selfreported good health and no depression symptoms.

The ordinal logistic regression analysis shows that the odds ratios of death or unhealthy survival among oldest-old women who gave 2 or $3+$ births after age 35 or 40 were $15-44$ percent lower in Models I, II, III, and IV, as compared with the women who did not have such late births. These estimates for females are all statistically significant, with one exception. The risk of death or unhealthy survival among very old males was found to be statistically significant among those who had 3+ births after age 35 or had 2 or $3+$ births after age 40 in Model I as compared with those who did not have late childbearing. The estimates also show that the association of having 2 or $3+$ births after age 35 or 40 and healthy survival is much stronger among the oldest-old women than the oldest-old men.

Comparing the estimates between Model II and Model I shows that the addition of the covariates of family support (including the number of surviving children) and social connections as controlling variables to the model moderately weakens the association between late childbearing and healthy survival. The addition of the covariates of health conditions into the models furthe weakens the association. These observations hold for both oldest-old women and men.

\section{Results based on the 1998 baseline survey data and the FAD method}

The 1998 survey shows that the fertility level among the three cohorts, aged 100-105, 90-95, and 80-85 in 1998, was similar. We also believe that the impact of giving birth at later ages on longevity and healthy longevity did not change significantly across the cohorts of our subjects. Thus, 
it may be reasonable to investigate the association between late childbearing and healthy longevity using the FAD method based solely on the 1998 survey data. Estimates of the ratio of survivorship show that women who had $1+, 2+, 3+$ births after age 35 would increase the likelihood of survival from age 80-85 to $100-105$ by 44,59 , and 127 percent, respectively, as compared to those women who did not have such late childbearing. The increase of the likelihood of survival from age 90-95 to $100-105$ due to having $1+, 2+, 3+$ births after age 35 is $32-53$ percent. These estimates are highly significant. The impact of having $1+, 2+, 3+$ births after age 40 on survival from age $80-85$ to 100 105 and from $90-95$ to 100-105 is even more dramatic - the increased likelihood of survival ranges from 102 to 322 percent and from 41 to 120 percent, respectively (see Table 4a).

The estimates also indicate that later childbearing is positively associated with the healthy longevity of women. The estimates of the ratio of healthy survivorship presented in Table $4 \mathrm{~b}$ show that giving birth after age 40 or 35 is positively associated with the likelihood of survival plus ADL independence. Most of the estimates are statistically significant; the association between giving birth after age 40 and healthy longevity is very dramatic and highly significant. The chance of surviving with ADL independence for women who gave 1+, 2+, 3+ births after age 40 increased by 133-542 percent from age $80-85$ to $100-105$, and increased by 62-235 percent from age $90-95$ to $100-105$, as compared to women who did not have late childbearing.

All of the estimates of the ratio of survivorship and ratio of healthy survivorship among the oldest-old men who had birth(s) after age 40 are greater than one; most estimates are statistically significant. The likelihood of surviving with ADL independence from age 80-85 to 100-105 for men who produced $1+, 2+$ and $3+$ children after age 40 was 58-143 percent higher, as compared to men who did not have late childbearing. The increases in the likelihood of healthy survival from age 9095 to 100-105 for the men who produced $1+, 2+$, and $3+$ children after age 40 were 11-43 percent. 
The likelihood of healthy survival from age 80-85 to 90-95 among the men who had $1+, 2+$, or $3+$ births after age 40 were $40-69$ percent higher than those who did not have late childbearing.

----Tables $4 \mathrm{a}$ and $4 \mathrm{~b}$ are about here----

\section{DISCUSSION}

A study using logistic regression, controlling for a few major socioeconomic factors and based on two large data sets from Great Britain and Austria, finds a positive relationship between giving birth after age 40 and longevity (Doblhammer, 2000). These results are consistent with two previous studies (Perls et al. 1997; Voland and Engel 1986). Perls et al. (1997) found that 19 percent of the 92 centenarians studied bore children after age 40, as compared with 6 percent of a control group of a similar cohort consisting of 49 women born in 1896, who died at age 73 . One possible explanation is that factors which were conductive to bearing child at later age might be also conductive in having aged at a slower pace and living longer. It is possible that later menopause is an additional marker. Snowdon et al. (1989) and Snowdon (1990) show that the mortality risk for women who had their natural menopause before age 40 is nearly twice as high as that of those who experienced menopause at age 50-54. It may be that the positive impact of late menopause results from the extended period of endogenous oestrogen production. A positive relationship between age at natural menopause and breast cancer (Heck and Pamuck, 1997), and an increase in the risk of breast cancer due to oestrogen therapies (Paganini-Hill, 1996; Law et al. 1996) have, however, also been found. The delay of menopause itself is perhaps unlikely to be the cause of increased longevity (Perls et al. 1997; Perls and Fretts, 2001).

In addition to the effects of an extended period of endogenous oestrogen production, later pregnancy, birth delivery, and breastfeeding may also stimulate women's biological systems and positively affect survival and health. Furthermore, some social factors might also contribute to the 
positive relationship between later childbearing and longevity. The contribution of social factors can be investigated through analyzing male fertility and longevity data. Doblhammer (2000) could not address this issue due to a lack of information on male fertility in her data sets. None of the previous studies investigated the association between late childbearing and longevity among men (Doblhammer 2000), except one recent study. Based on the Utah genealogical database, Smith et al. (2003) found that late age at last birth is associated with greater post-reproductive longevity among women; husbands of these women experienced weaker longevity benefits associated with late fertility.

The Chinese 1998 baseline and 2000 follow-up surveys on the determinants of healthy longevity collected data on fertility, health status, and mortality/survival from oldest-old men as well as women. This enables us to explore possible social factors, such as whether those very old people who had births at late ages may have advantages in healthy longevity partly because they had younger children to take better care of them. Statistical analysis based on the 1998-2000 follow-up data demonstrates that giving $3+$ births after age 35 or giving 2 or $3+$ births after age 40 is significantly associated with survival and healthy survival during the two-year period among the oldest-old Chinese women and men. The association of late childbearing with healthy longevity is stronger in oldest-old women than in their male counterparts. All of these statistical model estimates are adjusted for a variety of confounding factors of demographic characteristics, family support, social connections, health practice, and health conditions.

The FAD analysis based on the 1998 baseline survey shows that late childbearing, especially giving $3+$ births after age 35 or giving 2 or $3+$ births after age 40 , is positively associated with longterm survival and healthy survival from ages $80-85$ to $90-95$, and 100-105. This association exists among oldest-old women and men, but, again, the effects are substantially stronger in women than in 
men.

An extended period of endogenous oestrogen production, later pregnancy, birth delivery, and breastfeeding may stimulate biological systems and positively affect survival and health. This hypothesis may be true for women. The positive effect of later childbearing on survival and healthy survival for oldest-old men, however, cannot be explained by biological mechanisms related to late pregnancy and delivery. The effect thus indicates that various social factors may also be important. For instance, one possible explanation is that the oldest-old who had children after age 35 or 40 might receive better care from their relatively younger offspring. Other hypotheses are that the family atmosphere at middle age and elderly life might be more enjoyable if it includes babies and younger children. People with late childbearing might tend to take better care of their health because they have the responsibility of raising children and they may want to survive to see their children get married and produce grandchildren; such effects may continue from middle ages to advanced ages.

Based on the ordinal logistic regression analysis, we found that the oldest-old who had 2+ surviving children born after age 35 or 40 , with at least one such late-born daughter living nearby had statistically significant advantages in healthy survival, as compared to those who also had $2+$ surviving children born after age 35 or 40, but without a nearby late-born daughter. This indicates that young daughters may provide better care to their very old parents than do sons. This is consistent with the literature on the gender dimension of family care and intergenerational relations (Gerstel and Gallagher 1993; Grundy 2002; Grundy, Murphy and Shelton 1999; Légaré and Martel 2000, Zhi Yulin 2001; Zeng and George 2000).

Enlightened from the discussions in the literature (e.g. Hutchinson and Rose, 1991; Kirkwood and Rose 1991; Perls, 1997; Perls and Fretts, 2001; Perls, Kunkel, and Puca, 2002), our another hypothesis is that women who had $3+$ births after age 35 or 2 or $3+$ births after age 40 and who survived healthy 
up to the oldest-old ages 80-105 may have specific longevity gene(s) or other unobserved biological characteristics. Such genetic and/or biological characteristics may be associated with higher fecundity after ages 35-40 and healthy longevity among women. The genetic hypothesis may be less relevant among oldest-old men who gave $3+$ births after age 35 or had 2 or $3+$ births after age 40 . This is because the decline of fecundity with the increase in age among men is much slower than it is among women, and most men are able to provide fertile sperm after age 40, 45, or even 50, and thus produce late-born births if their wife or female partner is able to conceive (Check, 1989; Schill, 2001). In our sample, 16, 8, and 7 percent of the oldest-old men gave 1,2 , or $3+$ births respectively after age $45 ; 9,3$, and 2 percent of the oldest-old men gave 1,2, and 3+ births respectively after age 50 . The statistical analysis based on the 1998-2000 follow-up data shows that among oldest-old men, the association of late childbearing after age 45 or 50 with healthy longevity is similar to that of giving birth after age 40 .

In addition to possible biological and social factors, as discussed above, selection may also play an important role. It may be that physically robust and healthy persons are more likely to have children after age 40 and also enjoy healthy longevity. Rich and healthy men might have married much younger women, and thus had higher chances to have births at later ages.

It seems clear that late childbearing is significantly associated with health longevity at ages 80105. The magnitude of the effects of late childbearing on maternal mortality and healthy survival at middle age and the early stages of elderly life in China is, however, uncertain. We had no information for the early stages of the life course. It is possible that among the cohort members born 80-105 years ago, some women who gave birth after age 35 or 40 might have died due to difficulties in birth delivery or the extra burden and hardship of raising more children. The husbands of these unfortunate and perhaps genetically or biologically weak women might have died, too, because of sadness about the wife's death and the hard life in raising small children as a widowed father with poor resources. As 
Chen and Jones (1989: 73) noted, in high-mortality populations, the aged are those who have survived the dangers of being born, the risks of infancy and childhood, and the sicknesses and accidents of middle age. The sicknesses and accidents at middle age might include late-childbearing-induced delivery difficulties and maternal mortality and its associated psychological and physical losses.

In general, the oldest-old observed in the1998-2000 follow-up surveys are a selected group who survived the possible hardships of their middle-ages and are generally robust in health, and some of them may be genetically strong. Perhaps robust women who gave birth after age 35 or 40 were able to overcome the late-childbearing-induced difficulties during and after the deliveries, and, therefore, could survive to age 80-105. The weaker women who happened to give birth after age 35 or 40 might die due to problems during and after the deliveries. The selected more robust oldest-old women with late childbearing experience thus may have advantages in healthy survival. Research on the extraordinarily selected population of Chinese oldest-old (including women who gave birth after age 35 or 40 and are likely to be more robust) may provide important insights into why some people survive to advanced old age in good health (Zeng, Vaupel et al. 2001). Nevertheless, it is not appropriate to draw conclusions about the association of later childbearing with healthy survival at middle-ages and the early stage of elderly life among the Chinese based on this study, although European studies have indicated that such an association exists (Doblhammer 2000).

In sum, we believe that four factors may possibly explain why late childbearing may positively affect healthy longevity at advanced ages: (1) social factors; (2) biological changes caused by late pregnancy and delivery; (3) genetic and/or other biological characteristics associated with healthy longevity and higher fecundity; and (4) selection. The biological hypothesis, (2), is probably applicable to women only. The genetic and/or biological characteristics hypothesis, (3), may be more applicable to women and less relevant for men, but it is not clear how much of an effect genes may have and how 
large the gender differentials are. The social and selection hypotheses may be applicable to both women and men. Although relatively weaker as compared to the oldest-old women, the remarkable positive association of late childbearing with healthy longevity among the oldest-old men has led us to conjecture that social factors and selection are important in addition to biological and genetic factors.

\section{APPENDIX:}

\section{Physical and mental health variables}

The ADL functional statuses of eating, dressing, transferring, using the toilet, bathing, and continence are used to measure the elderly person's status of independence in daily living, based on the international standard of Katz' ADL index (e.g., Katz et al. 1963) adapted to the Chinese cultural/social context and carefully tested by pilot studies/interviews. In this article, if none of the six ADL activities is impaired, the elder is classified as "ADL active"; if one or more activities are impaired, the elder is classified as "ADL impaired".

The mental state of the Chinese oldest-old was screened by the Chinese version of the Mini-Mental State Examination, which was culturally adapted and translated into the Chinese language, based on the international standard MMSE questionnaire (Folstein et al.1975), and carefully tested by our pilot survey interviews. The Chinese version of the MMSE is appropriate to the cultural and socioeconomic conditions among oldest-old persons in China to make the questions easily understandable and practically answerable if the subject's cognitive function is normal (see Zeng, Vaupel et al. 2002, for details). A perfect score on the MMSE is 30; the methods for determining the score based on items pertaining to orientation, registration, attention, calculation, recall, and language are the same as the international standard. We also use the same cutoffs as the MMSE international standard to define a score of 24+ as "Normal cognitive function", and <24 as "Impaired cognitive function" (see, e.g., Deb 
and Braganza 1999; Osterweil et al. 1994).

Each interviewee was asked the question "How do you rate your health at present?", with possible answers being excellent, good, fair, poor or not able to answer; no proxy answers were allowed. Responses were dichotomized into very good/good versus fair/poor. Those oldest-old who were not able to answer the question on self-rated health due to health problems are included in the fair/poor category, which is a reasonable solution because the interviewees who were unable to answer the question were generally not in good health status.

The depression symptoms measure was based on answers to three questions about whether the subject "looked at bright side of things", "did not feel lonely", and "felt as happy now as when young". If an elder answered "no" to all of these three questions, he or she was classified as "no depression symptoms". Otherwise, he or she was classified as "having depression symptoms".

\section{Family support and social connections}

Marital status. Subjects who were widowed, divorced, separated or never married in 1998 were compared to those who were married.

The number of surviving children at the time of the 1998 survey is coded as $0,1-2,3-4$, and 5+.

Proximity with children. Subjects who live with children or have at least one child close-by (in the same village or on the same street) were compared with those who neither had children living with them nor had children living close-by.

Religious activities (more a social activity and not one looking at religiosity, such as personal prayer) was dichotomized into "do not participate" (83.6\%) and "participate almost everyday or sometimes" $(16.4 \%)$.

The social connection/support index was based on the following questions addressed to each interviewee. (1) Do you play cards or mah-jong regularly at the present time? (2) Do you watch TV or 
listen to the radio regularly at the present time? (3) Are retirement wages your first or second most important means of financial support? (4) Can you get adequate medical service when you are sick? (5) When you are sick, who usually takes care of you? The answer to questions (1) to (4) is "yes" or "no". If the answer is "yes", a score of 1 is given; otherwise, a score of " 0 ". The options for the answer to question (5) are (a) children and/or spouse; (b) other family members; (c) live-in caregiver; (d) friends;

(e) social service; (f) nobody. Those who provided answers (a)-(c) were given a score of "1"; the answers (d) and (e) were given a score of " 0.5 "; and the answer (f) was given a score of " 0 ". The sum of the scores covering these five questions was dichotomized at approximately the midpoint of the distribution of the sample into low and high social connection/support categories.

\section{$\underline{\text { Health practice }}$}

Cigarette smoking. Smoking was determined by the question "Do you smoke regularly at the present time?" Response options were "no" and "yes".

Alcohol consumption. Alcohol use was determined by the following three questions: (1) Do you drink alcohol at the present time? (2) If you drink alcohol at the present time, how much per day on average do you drink? The measurement unit employed in the answer was "liang", which is approximately equal to 50 grams and is a widely used unit in measuring alcohol consumption in people's daily conversations in China. (3) If you drink at the present time, what kind of alcohol do you mainly drink? The options for the answer were liquor, wine or rice wine. We code subjects into "strong alcohol drinker" if they drink more than two liang (100 grams) of liquor per day or more than six liang (300 grams) of wine per day or eight liang (400 grams) of rice wine per day; otherwise, the subject is coded as "not a strong alcohol drinker."

Diet. If a subject eats both meat and fresh vegetables often, he or she is considered as having a "healthy diet"; otherwise, he or she is considered as having an unhealthy diet. 
Exercise. If a subject currently does exercise regularly, he or she is coded as 'yes'; otherwise, 'no'.

Some self-assessed variables such as adequate medical service, diet, doing excises regularly, and depression symptoms are rather subjective, and we cannot collect objective data on these variables in our survey. The subjective answers are of limitations, but they may be useful proxy when the objective data are impossible to obtain. For example, many previous studies have demonstrated that self-assessed health acts as a significant and independent predictor of functioning and mortality of older people (e.g. Lee, 2000).

\section{References}

Allison, P. (2002). Missing data. Thousand Oaks, California: Sage Publications.

Barzilai, N. (1998). The Effect of Age on the Association Between Body-Mass Index and Mortality. Journal of the American Geriatrics Society. 46(6),799.

Check, J.H., Shanis, B., Bollendorf, A., Adelson, H., Breen, E. (1989). Semen characteristics and infertility in aging. Arch Andrology, 23, 275-277.

Chen, A.J., \& Jones, G. (1989). Aging in ASEAN: Its Socioeconomic Consequences. Institute of Southeast Asian Studies. Singapore.

Christensen, K. \& Vaupel, J.W. (1996). Determinants of longevity: genetic, environmental and medical factors, Journal of Internal Medicine 240(6), 333-341.

Clark, D.O.; Stump, T.E.; Hui, S.L. (1998). Predictors of morbidity and basic ADL difficult among adults aged 70 years and older. Journal of Aging and Health. 10(4), 422-440,

Coale, A., \& Li, S. (1991). The effect of age misreporting in China on the calculation of mortality rates at very high ages, Demography 28(2), 293-301.

Cox, D.R. (1972). Regression models and life tables (with discussion). J R Stat Soc. 34b, 187-220.

Deb, S., \& Braganza, J. (1999). Comparison of rating scales for the diagnosis of dementia in adults with Down's syndrome. Journal of Intellectual Disability Research 43(5), 400-407.

Doblhammer, G. (2000). Reproductive history and mortality later in life: A comparative study of 
England \& Wales and Austria, Population Studies 54 (2), 169-176.

Doblhammer, G., \& Vaupel, J.W. (2001). Lifespan Depends on Month of Birth. Proceedings of the National Academy of Sciences of the United States of America 98(5), 2934-2939.

Fillenbaum, G.G.(1988). Multidimensional functional assessment of older adults : the Duke Older Americans Resources and Services procedures. Hillsdale, NJ: Erlbaum Associates.

Folstein, M.F., Folstein, S.E., \& McHugh, P.R. (1975). Mini-Mental State: A practical method for grading the cognitive state of patterns of clinician. J Psychiat Res. 12, 189-198.

Gerdes, L.U., Jeune, B., Andersen-Ranberg K., Nybo H., \& Vaupel J.W. (2000). Estimation of Apolipoprotein E genotype-specific relative mortality risks from the distribution of genotypes in centenarians and middle-aged men: Apolipoprotein E gene is a "frailty gene," not a "longevity gene". Genetic Epidemiology 19, 202-210.

Gerstel, N. \& Gallagher, S. (1993). Kin keeping and distress: Gender, recipients of care, and workfamily conflict. Journal of Marriage and the Family 55, 598-607.

Grambsch, P.M., \& Therneau, T.M. (1994). Proportional hazards tests and diagnostics based on weighted residuals. Biometrika 81, 515-526.

Grundy, E. (2002). Gender and Ageing. Paper presented at the IUSSP (International Union for Scientific Studies of Population) Seminar on "Longer Life and Healthy Aging", October 22-24, Beijing.

Grundy, E., Murphy, M. \& Shelton, N. (1999). Looking beyond the household: intergenerational perspectives on living kin and contacts with kin in Great Britain. Population Trends 97, 33-41.

Harrell, F.E. (2001). Regression Modeling Strategies: with Applications to Linear Models, Logistic Regression, and Survival Analysis. Springer-Verlag, New York.

Heck, K. E., \& Pamuck, E.R. (1997). Explaining the relation between education and postmenopausal breast cancer, American Journal of Epidemiology 145(4), 366-372.

Hill, M. E. (1999). Multivariate survivorship analysis using two cross-sectional samples, Demography $36,497-503$.

Hitt, R, Young-Xu, Y., Perls, T. (1999). Centenarians: the older you get, the healthier you've been. Lancet, 354, 652.

Hosmer, D.W., Jr., \& Lemeshow, S. (1989). Applied Logistic Regression. New York: John Wiley \& Sons. 
Hutchinson, E. W. and Rose, M. R. (1991). Quantitative genetics of postponed aging in Drosophila melanogaster, I: Analysis of outbred populations. Genetics, 127,719-727.

Katz, S., Ford, A.B., Moskowitz, R.W., Jackson, B.A., \& Jaffe, M.W.(1963). Studies of illness in the aged-The index of ADL: A standardized measure of biological and psychosocial function. JAMA 185 (12), 914-919.

Kerber, R. A., O’Brien, E., Smith, K. R., \& Cawthon, R. M. 2001, "Familial excess longevity in Utah genealogies", Journal of Gerontology A Biological Science and Medical Science, Vol. 56, No. 3, Pp. B130-B139.

Kirkwood, T.B.L. and Rose, M.R. (1991). Evolution of senescence: Late survival sacrificed for reproduction. Philosophical Transactions of the Royal Society of London, B332,15-24.

Koenig, H.G., Hays, J.C., Larson, D., Geroge, L.K et al. (1999). Does religious attendance prolong survival? A six-year follow-up study of 3968 older adults. Journal of Gerontology: Medical Science 54A(7), M370-M376.

Landerman, L.R.; \& Fillenbaum, G.G. (1997). Differential relationship of risk factors to alternative measures of disability. Journal of Aging and Health, 9(2). 266-279.

Landerman, L.R., Land, K.C., \& Pieper, C.F.(1997). An empirical evaluation of the predictive mean matching method for imputing missing values. Sociological Methods and Research, 26(1), 3-33.

Law, T. M. Hesketh, P. J., Porter, K. A., Lawn-Tsao, L., McAnaw, R., \& Lopez, M. J. (1996). Breast cancer in elderly women: Presentation, survival, and treatment options, Surgical Clinics of North America 76(2), 289-308.

Lee, Y. (2000). The predictive value of self assessed general, physical, and mental health on functional decline and mortality in older adults. Journal of Epidemiology and Community Health. 54(2):123129.

Légaré, J. \& Martel, L. (2000). Living Arrangements of Older Persons. In Proceedings of the United Nations, Economic Commission for Europe, Population Activities Unit Conference on "Status of the Older Population: Prelude to the $21^{\text {st }}$ Century, Sion, Switzerland.

Mantel, N., and Haenszel, W (1959). Statistical aspects of the analysis of data from retrospective studies of diseases. Journal of the National Cancer Institute 22, 719-748.

Meurer, L.N., Layde, P.M., \& Fuse, C.E. (2001). Self-rated health status: A new vital sign for primary care? Wisconsin Medical Journal 100 (7), 35-39.

Osterweil, D., Mulford, P., Syndulko, K., \& Martin, M. (1994). Cognitive function in old and very old residents of a residential facility: relationship to age, education, and dementia. J Am Geriatr Soc. 42(7), 766-73. 
Paganini-Hill, A. (1996). Estrogen replacement therapy in the elderly. Zentralblatt für Gynäkologie $118(5), 255-261$.

Palmore, E.B.; \& Burchett, B.M. (1997). Predictors of disability in the final year of life. Journal of Aging and Health. 9 (3), 283-297.

Penning, Margaret J., Laurel A. Strain. 1994. Gender Differences in Disability, Assistance and Subjective Well-being in Later Life. Journal of Gerontology: Social Science, 49: s204.

Perls, T. (1997). Centenarians prove the compression of morbidity hypothesis, but what about the rest of us who are genetically less fortunate? Medical Hypotheses, 49(5),405-407.

Perls, T. T., Alpert, L., \& Fretts, R.C. (1997). Middle aged mothers live longer. Nature 389, 133.

Perls, T. She-Drinkwaterr, M., Bowen-Flynn, J., Ridge, S.B., Kang, S., Joyce, E., Daly, M., Brewster, S.J., Kunkel, L. and Puca, A.A. (2000). Exceptional familial clustering for extreme longevity in humans. Journal of American Geriatrics Society, 48, 1483-1485.

Perls T. T. and Fretts R. C. (2001). The evolution of menopause and human life span Annals of Human Biology, Vol. 28, no. 3, pp. 237-245 (9).

Perls, T., Kunkel, L., and Puca, A. (2002). The Genetics of Exceptional Human Longevity. Journal of the American Geriatrics Society, 50(2),359-368.

Preston, S.H., Hill, M.E., \& Drevenstedt, G.L. (1998). Childhood conditions that predict survival to advanced ages among African-Americans. Soc. Sci. Med.47, 1231-1246.

Puca, A. A., Daly, M. J., Brewster, S. J., Matise, T. C., Barrett, J., Shea-Drinkwater, M., Kang, S., Joyce, E., Nicoli, J., Benson, E., Kunkel, L. M., \& Perls, T. 2001, "A genome-wide scan for linkage to human exceptional longevity identifies, a locus on chromosome 4", Proceedings of National Academy of Sciences, U.S.A, Vol. 98, No. 18, pp. 10505-10508.

Schill, W.B (2001). Fertility and sexual life of men after their forties and in older age. Asian Journal of Andrology, 3, 1-7

Smith, J.B.; \& Kington, R. (1997). Demographic and economic correlates of health in old age. Demography, 34, 159-170.

Smith, K.R., Mineau,G.P., and Bean, L.L. (2003). Fertility and post-reproductive longevity. Special Biodemography Issue of Social Biology, in press.

Snowdon, D. A. (2001). Aging with Grace. New York: Bantam Books.

Snowdon, D.A., Kane, R. L., Beeson, W. L., Burke, G. L., Sprafka, J. M., Potter, J., Iso, H., Jacobs, D. R., \& Phillips, R. L. (1989). Is early natural menopause a biological marker of health and aging? American Journal of Public Health 79, 709-14. 
Snowdon, D.A. (1990). Early natural menopause and the duration of postmenopausal life: Findings from a mathematical model of life expectancy. Journal of the American Geriatric Society 38(4), 402-408.

Strawbridge, W.J., Cohen, R.D., Shema, S.J., \& Kaplan, G. A.(1997). Frequent attendance at religious services and mortality over 28 years. American Journal of Public Health. 87, 957-961.

Vaupel, J.W. (1992). Analysis of Population Changes and Differences. presented at the annual meeting of the Population Association of America, April 1992.

Voland, E. \& Engel, C. (1986). Ist das postmenopausale sterbealter variable einer fitnessmaximierenden reproduktionsstrategie? Anthropologischer Anzeiger 44(1), 10-34.

Wang, Z. L., Zeng, Yi, Jeune, B., \& Vaupel, J.W. (1998). Age validation of Han Chinese centenarians, GENUS - An International Journal of Demography, 54 (1-2), 123-141.

Yashin, A. I., Benedictis, G. D., Vaupel, J.W., Tan, Q., Andreev, K.F., Iachine, I.A., Bonafe, M., Luca, M.D., Valensin, S., Carotenuto, L., \& Franceschi, C. (1998). Combining genetic and demographic information in population studies of aging and longevity, Journal of Epidemiology and Biostatistics 3 (3), 289-294.

Yashin, A. I., Benedictis, G. D., Vaupel, J.W., Tan, Q., Andreev, K.F., Iachine, I.A., Bonafe, M., Luca, M.D., Valensin, S., Carotenuto, L., \& Franceschi, C. (1999). Gene, demography and life Span: The contribution of demographic data in genetic studies of aging and longevity. American Journal of Human Genetics 65, 1178-1193.

Yashin, A. I., Benedictis, G. D., Vaupel, J.W., Tan, Q., Andreev, K.F., Iachine, I.A., Bonafe, M., Luca, M.D., Valensin, S., Carotenuto, L., \& Franceschi, C. (2000). Genes and longevity: Lessons from centenarian studies, Journal of Gerontology: Biological Sciences 55A(6), B1-B10.

Zeng, Yi \& George, L. (2000). Family dynamics of 63 million (in 1990) to more than 330 million (in 2050) elders in China. Demographic Research 2.5.

Zeng, Yi, Vaupel, J.W., Xiao, Z.Y., Zhang, C. Y., \& Liu, Y.Z. (2001). The Healthy Longevity Survey and the active life expectancy of the oldest old in China. Population: An English Selection, 13(1), 95-116.

Zeng, Yi, James W. Vaupel, Xiao Zhenyu, Zhang Chunyuan and Liu Yuzhi. (2002). Sociodemographic and Health Profiles of Oldest Old in China. Population and Development Review, 28: 251-273.

Zeng, Yi and Jame W. Vaupel. (2002). Functional Capacity and Self-Evaluation of Health and Life of the Oldest Old in China. Journal of Social Issues, 58: 733-748.

Zhi, Yulin. (2001). Study on Intergenerational Interaction of 1,303 Elderly Persons in Urban Areas 
Zhejiang Province. Journal of Chinese Gerontology, Issue 3 of 2001: 81-82 (in Chinese).

\begin{abstract}
${ }^{1}$ The 22 surveyed provinces are Liaoning, Jilin, Heilongjiang, Hebei, Beijing, Tianjing, Shanxi, Shaanxi, Shanghai, Jiangsu, Zhejiang, Anhui, Fujian, Jiangxi, Shangdong, Henan, Hubei, Hunan, Guangdong, Guangxi, Sichuan, Chongqing. There are 31 provinces in total in China.
\end{abstract}

${ }^{2}$ Given the rapid economic development of China, some of the elders and their family who were interviewed in 1998 might have migrated to another area or moved to a new apartment or house in the same area, but sometimes no information on their new addresses was available. Thus, these people could not be followed up.

${ }^{3}$ The other nine provinces (Xinjiang, Qinghai, Ningxia, Inner Mongolia, Tibet, Gansu, Yunnan, Guizhou, and Hainan), all of which have a high proportion of inhabitants belonging to ethnic minorities, are not included in this study. While we are sure that the quality of age reporting is very poor in Xinjiang, it is not certain that the quality is poor or acceptable for all other ethnic minority groups in the other eight provinces that were not included in the survey. We did not include them because we are not sure about the quality of the age reporting of the ethnic minority groups in these eight provinces, and we had no detailed age-ethnic-specific data to evaluate them, and due to fund constraints.

${ }^{4}$ The validity of the proportional hazards assumption was examined and confirmed both graphically and with the normal score test of the proportionality (Grambsch and Therneau 1994) for the female survival analysis. For the male survival analysis, the proportional hazards assumption is confirmed graphically (Kalbfleisch \& Prentice1980; Hess 1995) and by the normal score test in most cases, with the exception that the category of males having 2 births after age 35 violated the proportionality assumption. We then tried other hazards models, such as Weibull, exponential, Gompertz, and loglogistic. Weibull and Gompertz hazards models produced almost the same results, as did the Cox proportional hazards model, and did a better job than the exponential and log-logistic model. We, therefore, decided to apply the Cox proportional hazards model to both the female and male survival analyses.

${ }^{5}$ The proportional odds assumption required for ordinal logistic regression was tested and met for both males and females.

${ }^{6}$ Based on the Chi-square tests suggested by Hosmer-Lemeshow (1989), we are satisfied with the goodness of fit of the logistic regression models presented in Table 2.

${ }^{7}$ We also separately estimated the association of late childbearing with healthy survival in the four main aspects of health status. The estimates of these four additional ordinal logistic regression models are generally consistent with the estimates presented in the last two columns of Table 3, and are available upon request.

${ }^{8}$ However, an analysis of the Cox proportional hazard model shows that there is no statistically 
significant difference in mortality between the oldest-old who had $2+$ surviving children born after age 35 or 40 with at least one such late-born daughter living nearby and those who also had $2+$ surviving children born after age 35 or 40 but without a nearby late-born daughter. The numerical estimates of the hazard model and ordinal logistic regression analysis are not presented in this article due to space limitations, but are available upon request.

9 The detailed numerical results are not presented here due to space limitations, but are available upon request.

${ }^{10}$ Concubine marriage was forbidden after 1950 by the new marriage law in China, but was rather common among rich men before 1950 .

11 Based on the international standard of Katz' ADL index (e.g., Katz et al. 1963) adapted to the Chinese cultural/social context and carefully tested by pilot studies/interviews, six questions about ADL functional statuses (can do it, can do it but need assistance, or cannot do it) were addressed to the oldest-old or a close family member if the elder was not able to answer. "Eating" refers to feeding oneself; "dressing" refers to getting clothes as well as dressing, including tying shoes; "transferring" refers to getting in and out of bed as well as in and out of a chair; "using the toilet" refers to going to the toilet and cleaning afterwards; "bathing" refers to sponge bathing, showering, tub bathing, or washing the body with a wet towel; "continence" refers to controlling urination and bowel movement.

12 Those oldest-old who were not able to answer the question on self-rated health due to health problems are included in the fair/poor category.

${ }^{13}$ According to these arbitrary criteria, the strong alcohol drinkers compose $7.3 \%$ of the entire sample, which is similar to the percent distribution of the category of $\geq 20$ drinking occasions (6.1\%) adopted in Koenig et al. (1999: M372). We also tried other criteria for defining the strong alcohol drinkers, and the results are more or less the same.

\section{References}

Chen, A.J., \& Jones, G. (1989). Aging in ASEAN: Its Socioeconomic Consequences. Institute of Southeast Asian Studies. Singapore.

Christensen, K. \& Vaupel, J.W. (1996). Determinants of longevity: genetic, environmental and medical factors, Journal of Internal Medicine 240(6), 333-341.

Coale, A., \& Li, S. (1991). The effect of age misreporting in China on the calculation of mortality rates at very high ages, Demography 28(2), 293-301.

Cox, D.R. (1972). Regression models and life tables (with discussion). J R Stat Soc. 34b, 187-220.

Deb, S., \& Braganza, J. (1999). Comparison of rating scales for the diagnosis of dementia in adults 
with Down's syndrome. Journal of Intellectual Disability Research 43(5), 400-407.

Doblhammer, G. (2000). Reproductive history and mortality later in life: A comparative study of England \& Wales and Austria, Population Studies 54 (2), 169-176.

Doblhammer, G., \& Vaupel, J.W. (2001). Lifespan Depends on Month of Birth. Proceedings of the National Academy of Sciences of the United States of America 98(5), 2934-2939.

Folstein, M.F., Folstein, S.E., \& McHugh, P.R. (1975). Mini-Mental State: A practical method for grading the cognitive state of patterns of clinician. J Psychiat Res. 12, 189-198.

Gerdes, L.U., Jeune, B., Andersen-Ranberg K., Nybo H., \& Vaupel J.W. (2000). Estimation of Apolipoprotein E genotype-specific relative mortality risks from the distribution of genotypes in centenarians and middle-aged men: Apolipoprotein E gene is a "frailty gene," not a "longevity gene". Genetic Epidemiology 19, 202-210.

Gerstel, N. \& Gallagher, S. (1993). Kin keeping and distress: Gender, recipients of care, and workfamily conflict. Journal of Marriage and the Family 55, 598-607.

Grambsch, P.M., \& Therneau, T.M. (1994). Proportional hazards tests and diagnostics based on weighted residuals. Biometrika 81, 515-526.

Grundy, E. (2002). Gender and Ageing. Paper presented at the IUSSP (International Union for Scientific Studies of Population) Seminar on "Longer Life and Healthy Aging", October 22-24, Beijing.

Grundy, E., Murphy, M. \& Shelton, N. (1999). Looking beyond the household: intergenerational perspectives on living kin and contacts with kin in Great Britain. Population Trends 97, 33-41.

Harrell, F.E. (2001). Regression Modeling Strategies: with Applications to Linear Models, Logistic Regression, and Survival Analysis. Springer-Verlag, New York.

Heck, K. E., \& Pamuck, E.R. (1997). Explaining the relation between education and postmenopausal breast cancer, American Journal of Epidemiology 145(4), 366-372.

Hess, K.R.(1995). Graphical methods for assessing violating of the proportional hazards assumption in Cox regression. Statistics in Medicine 14, 1707-1723.

Hill, M. E. (1999). Multivariate survivorship analysis using two cross-sectional samples, Demography $36,497-503$.

Hosmer, D.W., Jr., \& Lemeshow, S. (1989). Applied Logistic Regression. New York: John Wiley \& Sons. 
Kalbfleisch, J.D., \& Prentice, R.L. (1980). The Statistical Analysis of Failure Time Data. New York: John Wiley \& Sons.

Katz, S., Ford, A.B., Moskowitz, R.W., Jackson, B.A., \& Jaffe, M.W.(1963). Studies of illness in the aged-The index of ADL: A standardized measure of biological and psychosocial function. JAMA 185 (12), 914-919.

Kawas, C., Resnick, S., Morrison, A., Brookmeyer, R., Corrada, M., Zonderman, A., Bacal, C., Lingle, D.D., \& Metter, E. (1997). A prospective study of estrogen replacement therapy and the risk of developing Alzheimer's disease: The Baltimore Longitudinal Study of Aging, Neurology 48(6), 1517-1521.

Koening, H.G., Hays, J.C., Larson, D., Geroge, L.K et al. (1999). Does religious attendance prolong survival? A six-year follow-up study of 3968 older adults. Journal of Gerontology: Medical Science 54A(7), M370-M376.

Landerman, L.R., Land, K.C., \& Pieper, C.F.(1997). An empirical evaluation of the predictive mean matching method for imputing missing values. Sociological Methods and Research, 26(1), 3-33.

Law, T. M. Hesketh, P. J., Porter, K. A., Lawn-Tsao, L., McAnaw, R., \& Lopez, M. J. (1996). Breast cancer in elderly women: Presentation, survival, and treatment options, Surgical Clinics of North America 76(2), 289-308.

Légaré, J. \& Martel, L. (2000). Living Arrangements of Older Persons. In Proceedings of the United Nations, Economic Commission for Europe, Population Activities Unit Conference on "Status of the Older Population: Prelude to the $21^{\text {st }}$ Century, Sion, Switzerland.

Mantel, N., and Haenszel, W (1959). Statistical aspects of the analysis of data from retrospective studies of diseases. Journal of the National Cancer Institute 22, 719-748.

Menken, J. (1985). Age and fertility: How late can you wait? Demography 22 (4), 469-483.

Meurer, L.N., Layde, P.M., \& Fuse, C.E. (2001). Self-rated health status: A new vital sign for primary care? Wisconsin Medical Journal 100 (7), 35-39.

Osterweil, D., Mulford, P., Syndulko, K., \& Martin, M. (1994). Cognitive function in old and very old residents of a residential facility: relationship to age, education, and dementia. J Am Geriatr Soc. 42(7), 766-73.

Paganini-Hill, A. (1996). Estrogen replacement therapy in the elderly. Zentralblatt für Gynäkologie $118(5), 255-261$.

Perls, T. T., Alpert, L., \& Fretts, R.C. (1997). Middle aged mothers live longer. Nature 389, 133. 
Perls , T, and R. Fretts (2001). The evolution of menopause and human life span. Annals Human Biology, 28(3): 237-245.

Preston, S.H., Hill, M.E., \& Drevenstedt, G.L. (1998). Childhood conditions that predict survival to advanced ages among African-Americans. Soc. Sci. Med. 47, 1231-1246.

Seeman, E. (1997). Osteoporosis: trials and tribulations. American Journal of Medicine 103(2A), 74S$87 \mathrm{~S}$.

Smith, K.R., Mineau,G.P., and Bean, L.L. Fertility and post-reproductive longevity. Special Biodemography Issue of Social Biology, in press.

Snowdon, D. A. (2001). Aging with Grace. New York: Bantam Books.

Snowdon, D.A., Kane, R. L., Beeson, W. L., Burke, G. L., Sprafka, J. M., Potter, J., Iso, H., Jacobs, D. R., \& Phillips, R. L. (1989). Is early natural menopause a biological marker of health and aging? American Journal of Public Health 79, 709-14.

Snowdon, D.A. (1990). Early natural menopause and the duration of postmenopausal life: Findings from a mathematical model of life expectancy. Journal of the American Geriatric Society 38(4), 402-408.

Strawbridge, W.J., Cohen, R.D., Shema, S.J., \& Kaplan, G. A.(1997). Frequent attendance at religious services and mortality over 28 years. American Journal of Public Health. 87, 957-961.

Vaupel, J.W. (1992). Analysis of Population Changes and Differences. presented at the annual meeting of the Population Association of America, April 1992.

Voland, E. \& Engel, C. (1986). Ist das postmenopausale sterbealter variable einer fitnessmaximierenden reproduktionsstrategie? Anthropologischer Anzeiger 44(1), 10-34.

Wang, Z. L., Zeng, Yi, Jeune, B., \& Vaupel, J.W. (1998). Age validation of Han Chinese centenarians, GENUS - An International Journal of Demography, 54 (1-2), 123-141.

Yashin, A. I., Benedictis, G. D., Vaupel, J.W., Tan, Q., Andreev, K.F., Iachine, I.A., Bonafe, M., Luca, M.D., Valensin, S., Carotenuto, L., \& Franceschi, C. (1998). Combining genetic and demographic information in population studies of aging and longevity, Journal of Epidemiology and Biostatistics 3 (3), 289-294.

Yashin, A. I., Benedictis, G. D., Vaupel, J.W., Tan, Q., Andreev, K.F., Iachine, I.A., Bonafe, M., Luca, M.D., Valensin, S., Carotenuto, L., \& Franceschi, C. (1999). Gene, demography and life Span: The contribution of demographic data in genetic studies of aging and longevity. American Journal of Human Genetics 65, 1178-1193.

Yashin, A. I., Benedictis, G. D., Vaupel, J.W., Tan, Q., Andreev, K.F., Iachine, I.A., Bonafe, M., Luca, 
M.D., Valensin, S., Carotenuto, L., \& Franceschi, C. (2000). Genes and longevity: Lessons from centenarian studies, Journal of Gerontology: Biological Sciences 55A(6), B1-B10.

Zeng, Yi \& George, L. (2000). Family dynamics of 63 million (in 1990) to more than 330 million (in 2050) elders in China. Demographic Research 2.5.

Zeng, Yi, Vaupel, J.W., Xiao, Z.Y., Zhang, C. Y., \& Liu, Y.Z. (2001). The Healthy Longevity Survey and the active life expectancy of the oldest old in China. Population: An English Selection, 13(1), 95-116.

Zeng, Yi, James W. Vaupel, Xiao Zhenyu, Zhang Chunyuan and Liu Yuzhi. (2002). Sociodemographic and Health Profiles of Oldest Old in China. Population and Development Review, 28: 251-273.

Zeng, Yi and Jame W. Vaupel. (2002). Functional Capacity and Self-Evaluation of Health and Life of the Oldest Old in China. Journal of Social Issues, 58: 733-748.

Zhi, Yulin. (2001). Study on Intergenerational Interaction of 1,303 Elderly Persons in Urban Areas Zhejiang Province. Journal of Chinese Gerontology, Issue 3 of 2001: 81-82 (in Chinese). 
Table 1. Frequency distributions of variables of the interviewees aged $80+$ at the 1998 baseline survey included in the multivariate logistic, Cox hazards, and ordinal logistic regression models

\begin{tabular}{|c|c|c|c|c|c|c|c|c|c|}
\hline \multirow[t]{2}{*}{ Variables } & \multicolumn{2}{|c|}{ Number } & \multicolumn{2}{|c|}{$\%$} & \multirow{2}{*}{ Variables } & \multicolumn{2}{|c|}{ Number } & \multicolumn{2}{|c|}{$\%$} \\
\hline & $\mathrm{F}$ & $\mathrm{M}$ & $\mathrm{F}$ & M & & $\mathrm{F}$ & $\mathrm{M}$ & $\mathrm{F}$ & $\mathrm{M}$ \\
\hline ate childbearing variables & & & & & $\begin{array}{l}\text { Family support and social } \\
\text { connection (continued) }\end{array}$ & & & & \\
\hline ave birth after age 35 & & & & & Proximity to children & & & & \\
\hline 0 & 2434 & 1033 & 46.3 & 29.2 & Low & 1310 & 813 & 24.9 & 22.9 \\
\hline 1 & 1256 & 688 & 23.9 & 19.4 & High & 3952 & 2730 & 75.1 & 77.1 \\
\hline 2 & 849 & 651 & 16.1 & 18.4 & Social connection index & & & & \\
\hline $3+$ & 723 & 1171 & 13.7 & 33.1 & Low & 4031 & 1844 & 76.6 & 52.0 \\
\hline ave birth after age 40 & & & & & High & 1231 & 1699 & 23.4 & 48.0 \\
\hline 0 & 3687 & 1634 & 70.1 & 46.1 & $\begin{array}{l}\text { Number of surviving } \\
\text { children }\end{array}$ & & & & \\
\hline 1 & 988 & 792 & 18.8 & 22.4 & 0 & 783 & 428 & 14.9 & 12.1 \\
\hline 2 & 398 & 527 & 7.6 & 14.9 & $1-2$ & 1845 & 908 & 35.1 & 25.6 \\
\hline $3+$ & 189 & 590 & 3.6 & 16.7 & $3-4$ & 1667 & 1148 & 31.7 & 32.4 \\
\hline emographic variables & & & & & $5+$ & 967 & 1059 & 18.4 & 29.9 \\
\hline Age & & & & & Religious activities & & & & \\
\hline 80-89 & 1741 & 1787 & 33.1 & 50.4 & No & 4220 & 3144 & 80.2 & 88.7 \\
\hline $90-99$ & 1715 & 1298 & 32.6 & 36.6 & Yes & 1042 & 399 & 19.8 & 11.3 \\
\hline $100-105$ & 1806 & 458 & 34.3 & 13.0 & Health practice & & & & \\
\hline Residence & & & & & Currently Smoking & & & & \\
\hline Urban & 1912 & 1418 & 36.3 & 40.0 & No & 4876 & 2435 & 92.7 & 68.7 \\
\hline Rural & 3350 & 2125 & 63.7 & 60.0 & Yes & 386 & 1108 & 7.3 & 31.3 \\
\hline Education & & & & & Strong alcohol drinker & & & & \\
\hline 0 year schooling & 4562 & 1310 & 86.7 & 37.0 & No & 5087 & 3060 & 96.7 & 86.4 \\
\hline$\geq 1$ year schooling & 700 & 2233 & 13.3 & 63.0 & Yes & 175 & 483 & 3.3 & 13.6 \\
\hline Ethnicity & & & & & Healthy diet & & & & \\
\hline Han & 4878 & 3307 & 92.7 & 93.3 & No & 4121 & 2564 & 78.3 & 72.4 \\
\hline Minority & 384 & 236 & 7.3 & 6.7 & Yes & 1141 & 979 & 21.7 & 27.6 \\
\hline Age at first marriage & & & & & Currently exercising & & & & \\
\hline$\leq 18$ & 2772 & 891 & 52.7 & 25.1 & No & 4245 & 2176 & 80.7 & 61.4 \\
\hline $19-20$ & 1351 & 691 & 25.7 & 19.5 & Yes & 1017 & 1367 & 19.3 & 38.6 \\
\hline $21-24$ & 866 & 884 & 16.5 & 24.9 & Physical and mental health & & & & \\
\hline$\geq 25$ & 273 & 1077 & 5.2 & 30.4 & ADLs impaired & & & & \\
\hline & & & & & No & 2982 & 2581 & 56.7 & 72.8 \\
\hline & & & & & Yes & 2280 & 962 & 43.3 & 27.2 \\
\hline & & & & & Cognitive function impaired & & & & \\
\hline & & & & & No & 2295 & 2497 & 43.6 & 70.5 \\
\hline $\begin{array}{l}\text { amily support and social } \\
\text { nnection }\end{array}$ & & & & & Yes & 2967 & 1046 & 56.4 & 29.5 \\
\hline Married & & & & & Self-reported health & & & & \\
\hline No & 5000 & 2373 & 95.0 & 67.0 & Good/very god & 2615 & 2082 & 49.7 & 58.8 \\
\hline Yes & 262 & 1170 & 5.0 & 33.0 & Fair /poor & 2647 & 1461 & 50.3 & 41.2 \\
\hline Living alone & & & & & Depression symptoms & & & & \\
\hline No & 4702 & 3216 & 89.4 & 90.8 & No & 4437 & 3279 & 84.3 & 92.5 \\
\hline Yes & 560 & 327 & 10.6 & 9.2 & Yes & 825 & 264 & 15.7 & 7.5 \\
\hline
\end{tabular}

Notes: F: Females; M: Males.

Data Source: Chinese Longitudinal Healthy Longevity Survey - 1998 baseline. 
Table 2. Odds ratios reflecting effects of late childbearing on health status based on multivariate logistic regression at baseline survey, adjusted for covariates of demographic characteristics, family support, social connections, and health practice

\section{Gave birth after age 35}

Female (0 birth after age 35)

1 birth after age 35

2 births after age 35

$3+$ births after age 35

\section{ADL disabled}

MMSE impaired

\section{Self-reported bad}

health

Depression

symptoms

Hosmer-Lemeshow Chi-sqaure, df, and significant level of the model (Goodness-of-fit test)

$\begin{array}{llll}0.890 & 0.949 & 0.923 & 0.854 \\ 0.939 & 0.835^{\#} & 0.906 & 0.827 \\ 0.765^{*} & 0.772^{*} & 1.031 & 0.626^{* *}\end{array}$

$\begin{array}{llll}10.5(\mathrm{df}=8) & 9.4(\mathrm{df}=8) & 10.1(\mathrm{df}=8) & 12.8(\mathrm{df}=8) \\ (\mathrm{p}=0.235) & (\mathrm{p}=0.307) & (\mathrm{p}=0.256) & (\mathrm{p}=0.118)\end{array}$

Male (0 birth after age 35)

1 birth after age 35

2 births after age 35

$3+$ births after age 35

0.954
0.879
0.880

1.111

0.937

1.002

0.858

0.846

0.880

0.791

0.939

0.757

0.711

Hosmer-Lemeshow Chi-sqaure, df, and significant level of the model (Goodness-of-fit test)

$\begin{array}{llll}11.2(\mathrm{df}=8) & 6.8(\mathrm{df}=8) & 12.6(\mathrm{df}=8) & 14.8(\mathrm{df}=8) \\ (\mathrm{p}=0.193) & (\mathrm{p}=0.562) & (\mathrm{p}=0.126) & (\mathrm{p}=0.063)\end{array}$

\section{Gave birth after age 40}

Female (0 birth after age 40)

1 birth after age 40

2 births after age 40

\subsection{9}

0.987

$0.481 * * *$

0.890

0.979

1.022

1.153

$0.810^{\#}$

$3+$ births after age 40

0.765

0.837

$0.572 * *$

0.947

Hosmer-Lemeshow Chi-square, df, and significant level of the model (Goodness-of-fit test)

\section{$9.9(\mathrm{df}=8)$}

$(\mathrm{p}=0.269)$

\section{$9.1(\mathrm{df}=8)$}

$(\mathrm{p}=0.333)$

0.952
$0.707 *$
0.803

0.978

0.865

0.828

$8.9(\mathrm{df}=8)$

$(\mathrm{p}=0.348)$ $9.4(\mathrm{df}=8)$

$(\mathrm{p}=0.311)$ $6.2(\mathrm{df}=8)$

$(\mathrm{p}=0.622)$

$8.5(\mathrm{df}=8)$

$(\mathrm{p}=0.390)$

$0.616^{*}$

0.812

$0.562 *$

0.878

0.936

$3.0(\mathrm{df}=8)$

$10.4(\mathrm{df}=8)$

$(\mathrm{p}=0.241)$

Notes: (1) The category in parentheses is treated as a reference group. (2) The goodness-of-fit tests were performed following the approach of Hosmer and Lemeshow (1989). (3) df: degree of freedom. (4) \#, p<0.10; *, p<0.05; **, $\mathrm{p}<0.01 ; * * *, \mathrm{p}<0.001$.

Data Source: As for Table 1. 
Table 3. Relative risks and odds ratios reflecting effects of late childbearing on survival and healthy survival between 1998 and 2000 based on multivariate Cox proportional hazards and ordinal logistic regression models

\begin{tabular}{|c|c|c|c|c|}
\hline \multirow[t]{2}{*}{ Models } & \multicolumn{2}{|c|}{$\begin{array}{l}\text { Relative risk of Cox hazards models survival } \\
\text { analysis }\end{array}$} & \multicolumn{2}{|c|}{$\begin{array}{l}\text { Odds ratios of ordinal logistic regression } \\
\text { healthy survival analysis }\end{array}$} \\
\hline & Females & Males & Females & Males \\
\hline \multicolumn{5}{|l|}{ Gave birth after age 35} \\
\hline \multicolumn{5}{|l|}{ Model I (0 birth after age 35$)$} \\
\hline 1 birth after age 35 & 0.941 & 0.910 & 0.914 & 1.103 \\
\hline 2 births after age 35 & $0.850^{*}$ & 1.077 & $0.758 * * *$ & 0.930 \\
\hline $3+$ births after age 35 & $0.722 * * *$ & $0.747 * * *$ & $0.697 * * *$ & $0.769 * *$ \\
\hline \multicolumn{5}{|l|}{ Model II (0 birth after age 35 ) } \\
\hline 1 birth after age 35 & 0.941 & 0.919 & 0.977 & $1.209^{\#}$ \\
\hline 2 births after age 35 & $0.858 *$ & 1.100 & $0.847^{\#}$ & 1.045 \\
\hline $3+$ births after age 35 & $0.715 * * *$ & $0.800^{*}$ & $0.766 *$ & 0.895 \\
\hline \multicolumn{5}{|l|}{ Model III (0 birth after age 35 ) } \\
\hline 1 birth after age 35 & 0.949 & 0.919 & 0.967 & 1.157 \\
\hline 2 births after age 35 & $0.861 *$ & 1.116 & $0.828^{*}$ & 1.066 \\
\hline $3+$ births after age 35 & $0.720 * * *$ & $0.821^{\#}$ & $0.747 * *$ & 0.889 \\
\hline \multicolumn{5}{|l|}{ Model IV (0 birth after age 35$)$} \\
\hline 1 birth after age 35 & 0.977 & 0.947 & 1.003 & 1.169 \\
\hline 2 births after age 35 & 0.902 & 1.181 & 0.854 & 1.111 \\
\hline $3+$ births after age 35 & $0.767 * *$ & 0.889 & $0.791^{*}$ & 0.944 \\
\hline$-2 \log$ Likelihood (-2LL), Model I & $32138.0 * * *$ & $18981.1 * * *$ & $8577.6^{* * *}$ & $6360.1 * * *$ \\
\hline Improvement of $-2 \mathrm{LL}$, Model II vs Model I & $79.5 * * *$ & $47.6 * * *$ & $96.8 * * *$ & $50.3^{* * *}$ \\
\hline Improvement of $-2 \mathrm{LL}$, Model III vs Model II & $65.9 * * *$ & $71.9 * * *$ & $70.4 * * *$ & $98.5 * * *$ \\
\hline Improvement of-2LL, Model IV vs Model III & $231.4 * * *$ & $233.4 * * *$ & $286.1 * * *$ & $304.9 * * *$ \\
\hline \multicolumn{5}{|l|}{ Gave birth after age 40} \\
\hline \multicolumn{5}{|l|}{ Model I ( 0 birth after age 40$)$} \\
\hline 1 birth after age 40 & 0.925 & 0.908 & 0.945 & 0.978 \\
\hline 2 births after age 40 & $0.785 * *$ & $0.798 * *$ & $0.739 * *$ & $0.762 * *$ \\
\hline $3+$ births after age 40 & $0.569 * * *$ & $0.673 * * *$ & $0.560 * * *$ & $0.719 * *$ \\
\hline \multicolumn{5}{|l|}{ Model II (0 birth after age 40 ) } \\
\hline 1 birth after age 40 & 0.947 & 0.912 & 1.018 & 1.043 \\
\hline 2 births after age 40 & $0.791 * *$ & $0.792 *$ & $0.812^{\#}$ & $0.818^{\#}$ \\
\hline $3+$ births after age 40 & $0.568 * * *$ & $0.717 * *$ & $0.584 *$ & $0.817^{\#}$ \\
\hline \multicolumn{5}{|l|}{ Model III (0 birth after age 40) } \\
\hline 1 birth after age 40 & 0.942 & 0.935 & 1.000 & 1.076 \\
\hline 2 births after age 40 & $0.792 *$ & $0.798 *$ & $0.810^{\#}$ & $0.810^{\#}$ \\
\hline $3+$ births after age 40 & $0.565 * * *$ & $0.744 * *$ & $0.568 *$ & 0.842 \\
\hline \multicolumn{5}{|l|}{ Model IV (0 birth after age 40$)$} \\
\hline 1 birth after age 40 & 0.962 & 0.979 & 1.019 & 1.131 \\
\hline 2 births after age 40 & $0.811 *$ & $0.842^{\#}$ & $0.792 *$ & 0.850 \\
\hline $3+$ births after age 40 & $0.620 * * *$ & $0.782 *$ & $0.627 * *$ & 0.873 \\
\hline$-2 \log$ Likelihood (-2LL), Model I & $32135.0 * * *$ & $18981.2 * * *$ & $8578.2 * * *$ & $6359.1 * * *$ \\
\hline Improvement of $-2 \mathrm{LL}$, Model II vs Model I & $82.6 * * *$ & $46.2 * * *$ & $104.6^{* * *}$ & $48.3 * * *$ \\
\hline Improvement of $-2 \mathrm{LL}$, Model III vs Model II & $66.5 * * *$ & $71.0 * * *$ & $70.6 * * *$ & $98.6 * * *$ \\
\hline Improvement of -2LL,Model IV vs Model III & $230.3 * * *$ & $231.9 * * *$ & $285.0 * * *$ & $305.6 * * *$ \\
\hline
\end{tabular}

Notes: (1) The category in parentheses is the reference group. (2) Covariates in Model I are late childbearing plus demographic variables of age, gender, residence, education, and ethnicity. Model II is Model I plus covariates of family support \& social connection. Model III is Model II plus covariates of health practices. Model IV is Model III plus covariates of health conditions. (3) The number of degree of freedom for Model I to Model IV is 9, 17, 21, 25 respectively. (4) \#, p<0.10; *, p<0.05; **, p<0.01; ***, p<0.001.

Data Source: Chinese Longitudinal Healthy Longevity Survey - 1998 baseline and 2000 follow-up. 
Table 4a. Ratio of survivorship (RS) of elders who gave birth after age 35 or 40 to those who did not have such late childbearing

\begin{tabular}{|c|c|c|c|c|c|c|c|c|c|c|c|c|}
\hline \multirow[b]{2}{*}{$\mathrm{P}_{1}(\mathrm{x})$} & \multicolumn{4}{|c|}{ Ages $100-105$ vs. $80-85$} & \multicolumn{4}{|c|}{ Ages $100-105$ vs. $90-95$} & \multicolumn{4}{|c|}{ Ages $90-95$ vs. $80-85$} \\
\hline & $\overline{P_{1}(80-85)}$ & $P_{1}(100-105)$ & $R S$ & $P$ & $\overline{P_{1}(90-95)}$ & $\mathrm{P}_{1}(100-105)$ & $R S$ & $\mathrm{p}$ & $\begin{array}{l}\mathrm{P}_{1}(80-85) \\
\end{array}$ & $\mathrm{P}_{1}(90-95)$ & $R S$ & $\mathrm{p}$ \\
\hline \multicolumn{13}{|c|}{ Gave birth after age 35} \\
\hline \multicolumn{13}{|l|}{ Males } \\
\hline $1+$ births & 69.0 & 71.0 & 1.10 & 0.449 & 72.3 & 71.0 & 0.93 & 0.596 & 69.0 & 72.3 & 1.17 & 0.106 \\
\hline $2+$ births & 50.1 & 54.4 & 1.19 & 0.125 & 49.9 & 54.4 & 1.20 & 0.121 & 50.1 & 49.9 & 0.99 & 0.913 \\
\hline $3+$ births & 30.2 & 35.6 & 1.28 & 0.036 & 32.7 & 35.6 & 1.14 & 0.281 & 30.2 & 32.7 & 1.12 & 0.233 \\
\hline \multicolumn{13}{|l|}{ Females } \\
\hline $1+$ births & 49.8 & 58.8 & 1.44 & 0.000 & 51.3 & 58.8 & 1.35 & 0.000 & 49.8 & 51.3 & 1.06 & 0.489 \\
\hline $2+$ births & 24.6 & 34.2 & 1.59 & 0.000 & 28.2 & 34.2 & 1.32 & 0.001 & 24.6 & 28.2 & 1.20 & 0.059 \\
\hline $3+$ births & 8.9 & 18.1 & 2.27 & 0.000 & 12.6 & 18.1 & 1.53 & 0.000 & 8.9 & 12.6 & 1.48 & 0.005 \\
\hline \multicolumn{13}{|c|}{ Gave birth(s) after age 40} \\
\hline \multicolumn{13}{|l|}{ Males } \\
\hline $1+$ births & 48.9 & 57.9 & 1.43 & 0.001 & 57.6 & 57.9 & 1.01 & 0.926 & 48.9 & 57.6 & 1.42 & 0.002 \\
\hline $2+$ births & 25.2 & 37.6 & 1.79 & 0.000 & 33.7 & 37.6 & 1.18 & 0.158 & 25.2 & 33.7 & 1.51 & 0.000 \\
\hline $3+$ births & 10.8 & 21.2 & 2.21 & 0.000 & 17.1 & 21.2 & 1.30 & 0.070 & 10.8 & 17.1 & 1.70 & 0.000 \\
\hline \multicolumn{13}{|l|}{ Females } \\
\hline $1+$ births & 21.9 & 36.2 & 2.02 & 0.000 & 28.7 & 36.2 & 1.41 & 0.000 & 21.9 & 28.7 & 1.43 & 0.000 \\
\hline $2+$ births & 5.6 & 15.3 & 3.02 & 0.000 & 10.8 & 15.3 & 1.49 & 0.000 & 5.6 & 10.8 & 2.03 & 0.000 \\
\hline $3+$ births & 1.3 & 5.4 & 4.22 & 0.000 & 2.5 & 5.4 & 2.20 & 0.000 & 1.3 & 2.5 & 1.91 & 0.047 \\
\hline
\end{tabular}

Notes: (1) $\mathrm{P}_{1}(\mathrm{x})$ : Percentage of elders who gave birth after age 35 or after age 40 among those aged $\mathrm{x}$. (2) p:

Significance level of chi-square tests based on methodology provided by Mantel and Haenszel (1959) to test whether there is statistically significant difference of survivorship between those with the fixed attribute and those without the fixed attribute.

Data Source: As for Table 1. 
Table $4 \mathrm{~b}$. The ratio of healthy survivorship (RHS) of elders who gave birth after age 35 or after age 40 to those who did not have such late childbearing

\begin{tabular}{|c|c|c|c|c|c|c|c|c|c|c|c|c|}
\hline \multirow[b]{2}{*}{$\mathrm{P}_{1}(\mathrm{x}), \pi(\mathrm{x}+\mathrm{n})$} & \multicolumn{4}{|c|}{ Ages $100-105$ vs. $80-85$} & \multicolumn{4}{|c|}{ Ages $100-105$ vs. $90-95$} & \multicolumn{4}{|c|}{ Ages $90-95$ vs. $80-85$} \\
\hline & $\mathrm{P}_{1}(80-85)$ & $\pi(100-105)$ & $R H S$ & $\mathrm{P}$ & $P_{1}(90-95)$ & $\pi(100-105)$ & $R H S$ & $\mathrm{P}$ & $\mathrm{P}_{1}(80-85)$ & $\pi(90-95)$ & $R H S$ & $\mathrm{P}$ \\
\hline \multicolumn{13}{|c|}{ Gave birth after age 35} \\
\hline \multicolumn{13}{|l|}{ Males } \\
\hline $1+$ births & 69.0 & 71.4 & 1.12 & 0.506 & 72.3 & 71.4 & 0.95 & 0.778 & 69.0 & 72.3 & 1.17 & 0.151 \\
\hline $2+$ births & 50.1 & 56.3 & 1.28 & 0.103 & 49.9 & 56.3 & 1.29 & 0.097 & 50.1 & 49.2 & 0.96 & 0.709 \\
\hline $3+$ births & 30.2 & 39.3 & 1.50 & 0.010 & 32.7 & 39.3 & 1.34 & 0.069 & 30.2 & 31.5 & 1.07 & 0.556 \\
\hline \multicolumn{13}{|l|}{ Females } \\
\hline $1+$ births & 49.8 & 60.5 & 1.54 & 0.000 & 51.3 & 60.5 & 1.45 & 0.000 & 49.8 & 51.9 & 1.09 & 0.891 \\
\hline $2+$ births & 24.6 & 36.7 & 1.78 & 0.000 & 28.2 & 36.7 & 1.48 & 0.000 & 24.6 & 29.0 & 1.25 & 0.045 \\
\hline $3+$ births & 8.9 & 20.7 & 2.68 & 0.000 & 12.6 & 20.7 & 1.81 & 0.000 & 8.9 & 13.9 & 1.67 & 0.001 \\
\hline \multicolumn{13}{|c|}{ Gave birth(s) after age 40} \\
\hline \multicolumn{13}{|l|}{ Males } \\
\hline $1+$ births & 48.9 & 60.2 & 1.58 & 0.003 & 57.6 & 60.2 & 1.11 & 0.496 & 48.9 & 57.3 & 1.40 & 0.001 \\
\hline $2+$ births & 25.2 & 39.8 & 1.97 & 0.000 & 33.7 & 39.8 & 1.30 & 0.097 & 25.2 & 33.6 & 1.51 & 0.000 \\
\hline $3+$ births & 10.8 & 22.8 & 2.43 & 0.000 & 17.1 & 22.8 & 1.43 & 0.057 & 10.8 & 17.0 & 1.69 & 0.000 \\
\hline \multicolumn{13}{|l|}{ Females } \\
\hline $1+$ births & 21.9 & 39.5 & 2.33 & 0.000 & 28.7 & 39.5 & 1.62 & 0.000 & 21.9 & 29.7 & 1.50 & 0.000 \\
\hline $2+$ births & 5.6 & 18.4 & 3.77 & 0.000 & 10.8 & 18.4 & 1.85 & 0.000 & 5.6 & 11.7 & 2.21 & 0.000 \\
\hline $3+$ births & 1.3 & 8.0 & 6.42 & 0.000 & 2.5 & 8.0 & 3.35 & 0.000 & 1.3 & 3.4 & 2.59 & 0.005 \\
\hline
\end{tabular}

Notes: (1) $\mathrm{P}_{1}(\mathrm{x})$ : percentage of elders who gave birth after age 35 or age 40 among those aged $\mathrm{x} . \quad(2) \pi(\mathrm{x}+\mathrm{n})$ : percentage of elders who gave birth after age 35 or age 40 among those age $x+n$ and ADL independent. (3) p: Significance level of Chi-square tests based on methodology provided Mantel and Haenszel (1959) to test whether there is statistically significant difference of healthy survivorship between those with the fixed attribute and those without the fixed attribute.

Data Source: As for Table 1. 